\title{
nature
}

\section{Press tells it nearly like it is}

Can the United States survive a financial crisis and an election in the same year, and still keep its science enterprise intact?

THE science enterprise in the United States will this year pay a high price for the US government's profligacy over the past eight years. So much is clear from the noises emerging from the Congress. The administration's brave plan to double the budget of the National Science Foundation over a period of five years will be further postponed. The trouble now is the pact between the administration and the Congress that will limit discretionary spending in the financial year beginning in October to just over $\$ 3,000$ million, less than necessary to match inflation. (Defence spending is separate.) The administration wants most of such extra spending as there will be to be spent on science and technology. Congress, with an election in the offing, is going to push for more popular causes instead. This could be the first year since 1980 when spending on basic science marks time.

That is the sombre background of Dr Frank Press's address to the US National Academy of Sciences (of which he is president) last week. His tale may have been more cheerful than that of his British counterpart, Sir George Porter, a few weeks earlier, but even well-endowed enterprises may be seriously hurt when growth is brought suddenly to a halt. Press, last week, was chiefly concerned to anticipate the damage that may be done, and to fend it off. His case is the more persuasive because he acknowledged that US basic science is now in good shape because the government has invested generously in its support since almost the beginning of the Reagan presidency. The issue is that of how best to limit the damage that might be done

Press also last week accepted that the federal budget deficit must begin to shrink. The uneasy budgetary agreement between the administration and the Congress is meant to accomplish just that. Press is right to say that the the US government has no choice. There are some who will say that Press is wrong to acknowledge, as he did last week, that the Congress will not fall in with the administration's wish that virtually all of the $\$ 3,000$ million to spare in the agreed budget should be spent in the cause of basic science, but that is too puritanical a view. Congressmen (as distinct from Senators) must stand for re-election every two years precisely because of the calculation by those who framed the US constitution that they would thus be responsive to their electors' wishes. It is unrealistic to complain when, as on this occasion, congressmen decide that their constituents would prefer not to see the bulk of the funds available spent on science. It might well be different if congressmen were elected for longer terms of office, but there is not much time to legislate for that between now and November.

How then to limit the damage? Press asks that the scientific community should take the initiative in helping politicians to decide where to spend the funds available. That must surely be the correct strategy to follow. It may well be that many of the problems now afflicting British science would have been less daunting if the community of researchers had been more willing to acknowledge that their paymasters also had a problem or two to solve. Press's own recipe for damagelimitation has the particular virtue of being virtuously altruis- tic: he asks that, in scarcity, there should be "absolute priority" for spreading the funds available on training grants, fellowships and research grants reaching as many researchers as possible. Throw in national crises (AIDS) and notable opportunities (superconductivity, for example) and the Congress should know where to put the funds at its disposal.

The grant-making agencies would naturally find the going a little rougher. They will (or should) applaud Press's notion that the "pipeline" that supplies the talent for the research enterprise should remain full, but they may find that people appointed to research fellowships without a little money in their laboratory administrators' pockets to keep them out of mischief will eat out their hearts in discontent. But what matters is that the goal is laudable, and that its modesty should win support in the Congress even in an election year.

What comes next? People making public speeches listing categories of problems to be dealt with usually take care that there should be at least three of them. Not so Press, who lumps the rest of federally sponsored research and development into a single category of projects to be authorized now, but on which real money will not be spent until the US government has dealt with its financial problems. Building the Superconducting Super-Collider is one of these. Sequencing the human genome is another. The space station rates a mention only as an ingredient of the subcategory called the "political category". "It may be wise", Press said last week, "for multibillion-dollar projects like ( be left for major funding decisions by the next president, who will have the responsibility for seeing them done." In Washington's argot, that is a way of saying that the space station is, at present, at best a waste of money and probably a diversionary exercise (and thus actively harmful) as well.

Press's enemies will probably join his friends in asking whether the people who matter most will listen to him. His enemies will say that it is not for the likes of him to tell those elected to public office how to behave, or that it would make very little difference if they heard because they would not understand, but his friends should try to see that Press has embarked on an enterprise of outstanding originality-that of attempting to influence how the US government spends dwindling resources in a good and durable cause. Plainly it would be tactless for one in Press's job to go about the government town in which he works complaining that the space station is a waste of money, and probably a shot in the foot of the US economy as well. But his friends are more free to say those shocking things.

The issue travels further than the United States. The US research enterprise has many faults. Even in basic science, competition is unnecessarily cut-throat. Too many people work too hard and think too little. Useful applications repeatedly fail to materialize because the trade-off between the vaulting ambition of researchers and the empiricism of those who would exploit them is rarely made openly. Yet the US research enterprise remains the best model for understanding the natural world. Would it not be folly to let it turn to sand because there is a financial crisis in an election year? 